\title{
Between Utopia and Reality: Insecurity in Indigenous and Mennonite Communities in and Around the City of Filadelfia, Boqueron, Paraguay
}

\author{
Entre la Utopía y la Realidad: Inseguridad en las comunidades \\ indígenas y menonitas dentro y fuera de la ciudad de Filadelfia, \\ Boquerón, Paraguay ${ }^{1}$
}

\author{
Carlos Aníbal Peris Castiglioni \\ Universidad Nacional de Asunción, Paraguay \\ https://orcid.org/0000-0002-8205-3768
}

e-mail: cperis@rec.una.py

Recibido: 15/12/2020

Aprobado: 29/02/2021

\begin{abstract}
How can the social transformations of present-day Filadelfia, Boquerón, Paraguay be studied? In this article, new dynamics that show insecurity in Mennonite and indigenous communities are described. Qualitative interviews were carried out. Fourteen representatives were interviewed on: a) The main incidents that demonstrate vulnerability and, b) the identification of the aggressors as the Settlers. The reports provided by indigenous persons show that actions that are legal can still constitute a nightmare when exploitation and conditions of vulnerability are added. Regarding the Mennonite Settlers, they say that their youngmen in their desire to break the rules, consume, sell and introduce illicit drugs to their communities. Regarding the incidents of violence against women, those who force or abuse female members of the congregation are their fathers, brothers, uncles and grandfathers.

Keywords: vulnerability, violence, drug trafficking, abuse at work, Mennonites, indigenous groups.

\section{RESUMEN}

¿Cómo se pueden estudiar las transformaciones sociales de la actual Filadelfia, Boquerón, Paraguay? En este artículo se describen nuevas dinámicas que muestran inseguridad en las comunidades menonitas e indígenas. Se realizaron entrevistas cualitativas. Se entrevistó a catorce representantes sobre: a) Los principales incidentes que evidencian vulnerabilidad y, b) la identificación de los agresores como los colonos. Los informes proporcionados por indígenas muestran que las acciones que son legales aún pueden constituir una pesadilla cuando se agregan la explotación y las condiciones de vulnerabilidad. En cuanto a los colonos menonitas, dicen que sus jóvenes en su afán de romper las reglas, consumen, venden e introducen drogas ilícitas en sus comunidades. En cuanto a los hechos de violencia contra las mujeres, quienes fuerzan o abusan de las mujeres de la congregación son sus padres, hermanos, tíos y abuelos.
\end{abstract}

Palabras clave: vulnerabilidad, violencia, narcotráfico, abuso en el trabajo, menonitas, grupos indígenas.

\footnotetext{
1 Translated by 2nd and 4th year Translation Students, ISL Faculty of Philosophy; Celina Ferreira, Ingrid Galvan, Nicolas Morales, Rosa Sandoval and Cielo Caballero. Revised by 4th year Translation Student, Rosa Cristani and Prof. Laura Justice
} 


\section{INTRODUCTION}

The research for this article was carried out in the City of Filadelfia, Department of Boquerón, Paraguay, where an activist for the vindication of indigenous peoples, with a certain melancholy, commented: things occurred because some feel superior to others. To be honest this has been going on since immemorial times. Contrasts can be found everywhere: in their buildings, schools, neighbourhoods, even in the churches they attend (Interview No. 1: Indigenist - 09/28/2020).

Historical indigenous inhabitants were divided into four districts: Guidaiche (Ayoreos), Uj'e Lhavos (Nivaclés), Yvopey Renda (Guaraníes) and Cacique Mayeto (Enlhets) (General Department of Statistics and Census (DGEEC), 2012). They became known as urban indigenous persons and, although their population density was greater than any other community, they occupy the lowest section of the socio-economic structure. Their work became the manpower for the constructions of roads and routes, for the work in farms, gardens, and various other constructions. As expressed by the representative:

It is irrefutable that there are newcomers in these parts. Back in 2005 some Uruguayans came and today we can see Brazilians around. But don't you think that things have changed. The gaffer might change, but the rest remains the same. Indigenous persons suffer insecurity. It begins in their place of work, but it continues in the use and trafficking of drugs and in human trafficking. It is a fact that when there are large numbers of people, diverse amongst themselves, vulnerabilities increase, and this has also happened among ethnic groups. (Interview No. 1: Indigenist - 09/28/2020).

On the other side of the coin, a Mennonite representative of the Museum Casa Colonial, tells us about the spirit that motivated his ancestors in those initial years in Central Chaco: 'we had three principles that guided us. First, work along with a prayer. Second, the community comes before the person. Third, remember why we came here, running away from Stalin and seeking freedom (Interview No. 2: Culture Representative - 09/27/2020).

The Mennonites settled in the Chaco in the 1930s. Having come from the former Soviet Union, they founded the Cooperative Fernheim (Long-distance Home in German). They became known for their dairy products (Lacteos CO-OP), their beef products (Frigochaco and Don Pepe), their tourism (Hotel Florida), their peanut and sesame plantations (Agrochaco, a company dedicated to selling agricultural supplies), and their leather exports (CENCOPROD, an alliance of the three largest credit cooperatives in the Paraguayan Chaco, with Chortitzer and Neuland Cooperatives, credit cooperative companies), (Sub Secretariat of State Taxation Agency, SET 2020). After almost five generations, they have become the economic elite. Despite the advantageous situation, they say that:

Things have changed, we can now see Belgians, Germans and Latinos around. It seems this is now a multicultural community where we have become a minority. What our grandparents once conceived as their dream seems far away now. Although to a lesser extent, it is a reality that we do not escape from the problems of crime and drug addiction (Interview No. 2: Culture Representative - 09/27/2020).

The first reports, from different perspectives, show that the city has had to deal with the deep metamorphosis it has experienced. It is no longer just the indigenous living alongside the Mennonites. New immigrants have arrived creating a new context. At this point, the guiding question of this work appears: How to study the social transformations of present-day Filadelfia? 
In this regard, both representatives speak about insecurity, some related to the use of narcotics, abuse at work and others about sexual exploitation. Taking into account the above, we intend to describe the dynamics in relation to what has been identified as modern insecurities. By applying qualitative interviews to community leaders, the article has been set to address what is defined as insecure, among both Indigenous Communities and Mennonite Settlers.

It is worth clarifying, however, that this text was developed from a perspective of research in progress. In addition to the Introduction, Materials and Methods sections, the testimonies of the two sectors were added in accordance with the main inquiry. The reader will not find on the following pages a hypothesis or a theoretical exposition, but rather, preliminary results obtained in the field.

\section{MATERIALS AND METHODS}

The research was carried out in the City of Filadelfia, Department of Boquerón, Paraguay, between September $27^{\text {th }}$ and September $30^{\text {th }}, 2020$. A total of 14 Community leaders were interviewed, from which information on changes in the locality were obtained through what was defined as insecure. What are the main events that show that there is vulnerability? and who are the persons that have been established as the aggressors? These are the specific questions that guided this work.

The methodology, typified in qualitative, was carried out by in-depth interviews. Thus, it has sought to obtain testimonies, the result of personal reflections of those consulted. They have been left under anonymity and selected, consequently, by: a) importance and significance of their role in the Mennonite and Indigenous Communities; (b) City Authorities; (c) Government Representatives; and, d) Journalists.

The list of sources was consolidated according to their order of appearance in this Article: No.1: Indigenist - 28/09/2020.

- No. 2: Cultural Representative - 30/09/2020.

- No. 3: Municipal Council for the Rights of Children and Adolescents (CODENI) Officer 29/09/2020.

- No. 4: Indigenous Leader - 28/09/2020.

- No. 5: Filadelfia Councilperson - 28/09/2020.

- No.6: Local Journalist - 29/09/2020.

- No.7: National Anti-drug Secretariat (SENAD) Informant - 29/09/2020.

- No. 8: District Attorney - 30/09/2020.

- No.9: Fernheim Cooperative Representative - 28/09/2020.

- No. 10: Mennonite Psychopedagogue - 29/09/2020.

- No. 11: Filadelfia National Police Officer - 30/09/2020.

- No. 12: Mennonite Leader - 29/09/2020.

- No. 13: Judiciary Official-28/09/2020.

- No. 14: Municipal Official-27/09/2020.

\section{ANALYSIS OF RESULTS No.1:}

\section{VULNERABILITY AMONG INDIGENOUS POPULATIONS}

At the beginning of the research we focused on the insecurities endured by indigenous populations of the area. We interviewed a local representative of the Municipal Council for the Rights of the Child and Adolescent (CODENI), who alluded the following:

What the indigenous persons endured is directly related to the legal registration of inhabitants. I mean, a lot of them are not registered and, by not having an ID, it is 
almost impossible for them to have access to the existing protection mechanisms. You don't know where to start. We try to accompany them in the process of obtaining an Identity Document, but it is difficult. There are cases where mothers or grandmothers have been located, but tracking the family lineage is very complicated. They have fallen into a void that generates disadvantages that some benefit from (Interview No. 3: with a representative of the Municipal Council for the Rights of Children and Adolescents (CODENI) - 29/09/2020).

It is undeniable that a significant number of indigenous persons have no official documents. In 2015, a census was carried out in order to start a campaign, at the national level, to address this problem. The study showed that $36 \%$ of the registered inhabitants were undocumented - (Ultima Hora, local newspaper, 06/07/2015). In October 2020 government authorities admitted that the legalization process was complicated and much remains to be done (Ultima Hora, local newspaper, 26/10/2020). The fact that they are not registered has created citizens who exist and inhabit the land but cannot enjoy the guarantees of the State. This situation caused multiple forms of vulnerabilities that are used by persons with ulterior interests, sometimes for illegal purposes.

Regarding this, a representative of one the communities we studied, discussed the vicissitudes they endure. He described situations of abuse characterized by a total lack of empathy and of atrocity:

We have to work excessively long hours, very badly paid, and often, after finishing the task in the intense and oppressive heat, the contractor leaves without giving you anything, abandoning you to your fate on the road. The Chaco itself is difficult and the reality that I am telling you makes it unbearable. Here there are those who believe that, because they speak another language and they own property, that gives them power over their others (Interview No. 4: Indigenous Leader - 09/28/2020).

Furthermore, a representative from Filadelfia City Council added the reasons why the described situation arose:

It's not that there is a disrespectful treatment towards indigenous peoples. The gaffer is a kind of moneylender. He gives them money to buy their motorcycles and, of course, this makes him a bit demanding. For an outsider this might seem bad, but to us this is normal. We know who they are dealing with and how they have to work in the future. For example, the Ayoreos must be given short and heavy tasks, the Nivaclés gardening and the Enlhets and Guaranies bricklaying or plumbing jobs (Interview No. 5: Representative of Filadelfia City Council - 28 /09/2020).

The author does not intend to be subjective or to take a hard position regarding the above content, but arguments based on reification, and stereotyping of indigenous peoples have been evident in many interviews, revealing a feeling of possession on the part of those providing "job opportunities", terms used repeatedly in the interviews. The fact that this corroborates the allegations of precariousness and abuse in the workplace, which affects indigenous adults and youth. A CODENI contact explains that:

In Filadelfia, it is common to start working at an early age, while still young. We often see young men helping with yard work, in the stores or hotels, that's not bad. What is reprehensible, and it doesn't only occur to teenagers, is that those who provide the services are being exploited. When I say exploitation I mean the unpleasant situations of 
terrible pay, long hours, without any type of rest and being left at the pure mercy of the gaffer (Interview No. 3: a CODENI representative - 09/29/2020).

Similarly, a journalist from a regional radio station, reflects:

Since the idea that there is no equality is accepted, the Mennonites do whatever they want. They assume that they have the power and cross the line. I told you about my friend whose boss beat him up. It was in a slaughterhouse in Loma Plata. Chronicles of this type are countless. The dangers are not limited to robberies or assaults, but they include the adversities they find in their endeavor to obtain their daily sustenance (Interview No. 6: Local Journalist - 09/29/2020).

At this point, the insecurity factor emerged in the context of what was experienced by the indigenous worker. Whether it is through the testimonies of the Municipal Official, the Council Representative, the CODENI, the community leader, or the social spokesperson, there is a latent and constant harming of indigenous persons in their workplace. This unfortunate scenario occurs due to the express violence, such as in the case of aggression in a slaughterhouse, or an indirect grievance in the form of an unjust salary, the long work hours or the employment of children in places that are not appropriate for them and their cognitive condition. The origin of this insecurity lies with the employers themselves, mostly, the Mennonite settlers. The victims, due to their vulnerability and lack of access to protection mechanisms, are members of the four urban ethnic groups in the city.

The detailed lassitude, however, has not only manifested itself in the legal jobs undertaken by them, but it also adds up to the poverty that often, forces indigenous persons to accept dangerous jobs trafficking drugs. In this regard, an official from the National Antidrug Secretariat $(S E N A D)$ stated that:

Everyone knows that in the Central Chaco there are clandestine posts where Bolivian cocaine is delivered. The merchandise is dropped over cattle ranches, some of which are managed by Brazilian migrants, taking advantage of the strategic geographical triangle between Bolivia, Paraguay and Brazil. Now, who do you think takes the fuel supply or brings the light-plane trailers? It is always the indigenous persons. Furthermore, in most expeditions, they are the ones who fall and end up in Court, sometimes unfairly. (Interview No. 7: National Antidrug Secretariat (SENAD) Informant - 09/29/2020).

Often, mass information media have reported ilegal landingstrips in the Chaco. On July 18, 2020, half a ton of cocaine was seized at a cattle-ranch located in Toro Pampa, Alto Paraguay. Likewise, in December 2019, more than 300 kilos were seized at 10 de Diciembre establishment, in Teniente Esteban Martínez, Presidente Hayes. This together with the two testimonies constitute tangible and constant evidence that drug trafficking is present in the area. A specialized attorney explains:

I'll explain it to you: in the Chaco there is a constant movement of illegal substances and, in the locations indicated as red spots, there are indigenous persons who were found directly, micro-trafficking, or indirectly involved in drug trafficking operations. Firstly, in Puerto Casado, Alto Paraguay Cannabis is passed from the Eastern to the Western Region in rafts that belong to indigenous persons. Secondly, in Mayor Infante Rivarola, Boquerón, in the border with Bolivia, cocaine is transported by land, many of the mules are indigenous persons. Then, there is the case of Pozo Hondo, Boqueron, in the border with Argentina, where cattle, coca leaves, and Cannabis are also moved by members of indigenous communities. And, fourthly, the landingstrips are in Fuerte Olimpo, Bahía 
Negra, Carmelo Peralta and Toro Pampa, all in Alto Paraguay Department. Indigenous persons fill the diesel tanks. (Interview No. 8: District Attorney - 09/30/2020).

If in the first form of insecurity we observed abuse and an absence of rights in the workplace, here we can see that destitution and misery have sprung up and forced historic indigenous settlers to accept dangerous jobs where their own existence was put at risk. We must remember the publication of the non-profit organization Tierra Viva, called Violence and Impunity towards the Paĩ Tavyterã-Kaiowá town in the Department of Amambay, in the Eastern Region. The document reports assassinations of Paĩ Tavyterã members at the hands of mafias (particularly drug-related) installed in the country, starting in the 1990s (2014, p. 9). If we connect bibliographic antecedents with the testimonies in the present investigation, we can verify that indigenous peoples have been coerced by drug trafficking cartels. Members of different indigenous communities who came across their business have been under constant threat.

The social activist, mentioned in the Introduction, spoke about this issue:

Filadelfia is one of the most developed towns in the Chaco. Here you won't find illegal runways, but indigenous persons who were imprisoned in Alto Paraguay or Presidente Hayes and settled in one of Filadelfia's neighborhoods. You have to understand that they walk great distances for their work. They have many necessities. Drug traffickers are clever and offer them jobs, so they gather what little they have by way of belongings in a backpack and leave. They always say that they will look after the labourers. When will they return? It is a mystery, left to their own devices and God's will. (Interview No.1: Indigenist - 28/09/2020).

The extent of insecurity can be seen when looking at the administrators of the cattle-farms engaged in illegal activities. Several testimonies identify them as Brazilian men who, aware of their extremely poor environment, used and abused the four tribes. The Public Ministry informant stated that:

The drug trafficking networks rely on them because they are cheap and also, they can use force if something gets complicated. They are also used as bait. They are totally in their hands. There are no records of indigenous persons being murdered, but there are of threats. They know it is illegal, but they will not denounce it. They submit to the trafficker's interests. To a trafficker, life has no value, and here it is worse because of their vulnerability and poverty. (Interview No. 8: District Attorney - 30/09/2020)

Although other situations are tolerated, some identified as human trafficking, poaching or undue tourism by German, French, North American, Uruguayan or Argentinean travellers, the two main ones are those relating to workers exploitation land drug trafficking. In both an absence of rights and precariousness could be observed, which in turn are breeding grounds for other transgressions, some of which are exacerbated by the inaction of the state authorities.

In short, the situation of Filadelfia's native communities was described as hopeless, both historic and present-day. As a consequence, outsiders took advantage of them for their personal benefits, either in the drug trade or in occupational scenarios, repeatedly defined as quasi slavery. The violation and non-recognition of the dignity of the person has been latent, as well as the sense of superiority on the part of some. Therefore, we can see the extent of the insecurity suffered by native communities in Filadelfia. 
ANALYSIS OF RESULTS No. 2:

\section{INSECURITY SUFFERED BY THE MENNONITE POPULATION}

Despite being founded on August 17th in 1931, the city of Filadelfia celebrated its first elections in 2006. Choosing the Mayor and the city councillors, as easy as it might seem in any place with a long-standing democracy, was not a simple task in this case. From 1931 until 2006, the structure revolved around the Fernheim Cooperative. This was the core of the city's order and also the moral compass that dictated what was right and what was wrong for the Filadelfia's inhabitants.

Becoming an autonomous jurisdiction with national status in the departmental capital of Boquerón entails an impact of the State and its Institutions on the community. In the old days, conflicts were sorted in the Church, nowadays they are settled in the Courts. In the past it was the Pastor who imposed the punishments and were in control, today it is the police. The changes mean that Mennonites have to live with organizations, norms and cultural trends, many of which are foreign to them. In the words of a community Leader,

In the old days, it was our Religious leaders who made the rules and when something bad or controversial happened we went to them. Now there are representatives of the Public Ministry, from central offices, people from the National Antidrug Secretariat (SENAD), in short, a large number of actors that have come and confused the settlers. People here do not know when to turn to these bureaucrats and, if a problem arises, they might go and ask the attorneys ¿do I have to pay for you to free my son? I will go and sort this problem in the church later. (Interview No. 9: Leader of the Fernheim Cooperative 28/09/2020)

A specialist in youth behaviour, educated in Asunción who describes himself as an openminded individual while consistent with his people's traditions, explained:

There is something both amusing and tragic going on here. They insist that the norms and the authorities are foreign to them, but they strive to live as they do in big cities. They follow fashion trends and want to see the world. This phenomena did not happen to the grandparents nor to the parents, but it is happening to the children. You cannot imagine the mischiefs they get up to. They organise huge raves at their parents' farms, where all sorts of things circulate (Interview No. 10, Mennonite psychopedagogue 29/09/2020)

Based on the testimonies, this is a conservative society filled with taboos, that in recent times went through innovative ways of interaction, especially amongst the young who do not want to follow in their ancestor's footsteps. Many testimonies show the rebelliousness of the new Mennonites who, aware of their economic power, have turned to illegal substances. A Police Officer comments:

They are a pain for their families. They do drugs. They show off their cash and can splurge in organising huge events. It's not the outsiders who introduce the drugs. They sell them to their friends. It's considered socialising. Smelling this stuff is breaking paradigms and appeasing their desire to get out of an environment that is oppressive and full of prejudice and limitations (Interview No. 11: National Police in Filadelfia30/09/2020). 
Drug consumption here is not due to precariousness or vulnerability. Instead, and consequently, it occurs due to the economic flow that allows teenagers to dabble in this vice. A leader of the community highlighted:

These children are the fourth or fifth generation. They believe that there is no such thing as the fruit of work and effort, but rather what is inherited. They want to have fun following the trends that came to break the values. They use cocaine for recreational purposes. It is suspected that it comes from Asuncion and Bolivia "it is an open secret". The drugs arrive in cars and motorbikes that are brought over together with other products by the macatheros. They are the ones that provide the kids with the stuff they then hand out at the parties. There is an excessive amount of supply and demand. (Interview No. 2: Mennonite Leader- 29/09/2020).

Insecurity as the main factor that has sprouted from the addiction to narcotics according to the settlers. The agents of insecurity have been Mennonite teenagers. Drug addiction has not caused deviant behaviour, such as theft, assaults, and daily brigandage. It represented the stigma that ruined those that were involved. Their parents want to keep the cases under wraps and propose alternative solutions to the conflict, so they resort to corruption. An attorney explains:

First, they tell you that their child isn't involved in this. Then you show them the pictures and texts in the phones. They have no choice but to accept the irrefutable. Then they try some sort of bribery. If the boys have money, it's because their parents or legal guardians, have it, and they feel they are entitled to offer you money in exchange for their freedom (Interview No. 8: Local Attorney -30/09/2020).

According to this information, the population underwent two processes: a) the group of youths' disobedience that incorporated the use of narcotics, and; b) the retention of them and the inexperience in dealing with it, from both their parents and Paraguayan authorities. This context could potentially worsen because this takes place in a city prone to maintaining the status quo and it does not have a rehabilitation centre. A journalist states:

Apart from awareness campaigns and meetings to offer them help, not much has been done. The detoxification hospitals and those who could offer specific treatment have remained absent. It is a growing problem that could blow up in our faces (Interview No.6: Local Journalist- 29/09/2020).

The second form of insecurity finds its origins in the relationships amongst family members, conflicts within the family. The State has established alternative reporting mechanisms, which were used by women, wives, and daughters who have had enough with their partners' or parents' abuse. We interviewed Police Officer who stated the following:

Everything is a taboo. Controversial issues are seldom discussed at the Station. It is a fact, however, that there are more and more cases. They have realised that problems don't disappear just by attending church, they have no choice but to inform themselves and learn about the government's protection systems, so they can come and ask for our help. We are talking about a town that has remained quiet for too long. They are slowly becoming aware that the way things used to be done, no longer work (Interview No.11: National Police in Filadelfia - 30/09/2020). 
An experienced Judiciary representative who worked for 10 years in the colony, explains Fildadelfia's recent migratory waves phenomenon.

There are Uruguayans, Germans and French men and women living here. Mennonite girls see the other nuclei and begin to think that their way of life is outdated. It is not normal to partake in arranged marriages, it is not right to be wed at the age of 13, or to do solely what the man says, locked away in your house subject to your partner's every whim (Interview No.13: Judiciary Official -27/09/2020).

Witness accounts agreed that the violence endured by women in terms of physical and psychological abuse is perpetrated by their grandfathers, fathers, uncles, and brothers. In other words, they are part of their immediate circle. This can be seen in the cases of early pregnancies, sexual coercion, civil unions with minors, aggressions, and femicides. This means that the numbers that reached the public opinion are much lower than the actual number of cases that have gone unreported. Often the disputes are treated only in religious councils. Some of them never come to light.

The Mennonite leader states that

Mennonite women can now divorce, and this is what sparked arguments within their families. It is a male-dominated society, therefore, there are countless cases of domestic abuse. Women are relegated to a secondary plane in the church, in the cooperative and in the workspace. There has also been an increase in femicides and physical aggressions. Much attention has been given to this issue, and they no longer tolerate their ancestors' practices (Interview No. 12: Mennonite Leader- 29/09/2020).

Insecurity here is prompted by Mennonite men. Just like the phenomenon of drug addiction amongst Menonite teenagers, these are not originated by external agents but by members of the community. In this case it is not because of a desire to explore unknown horizons, but the discontent with the oppressive and subjugating way of life imposed on female members of the community for the sole reason of being born women. Women feel more empowered after observing different behaviour patterns and interactions in other families in other groups. When leaders of the cooperative are questioned about this issue, it produces reactions based on guilt, outside the community, as stated by a representative of the Cooperative.

Foreign logics are imposed on us. When they see what we have achieved, and that thanks to our work this place exists, foreigners and delegations from Asuncion show up. But they show no respect for our values. They bring their worldviews to break down our dreams for our community (Interview $\mathrm{N}^{\circ}$ 9: Fernheim Cooperative Representative - 09/28/2020). The councillor added that:

Adult Mennonites say 'this belongs to us because if everyone can enjoy it know it is because of the work we put into it at the beginning, it's only right'. It is easy to put yourself in a moralistic position and shout that this is wrong. It is simple because the structure of civilization was established by our great-grandparents, who came to a land that nobody wanted (Interview $\mathrm{N}^{\circ} 5$ : Councillor of Filadelfia - 28/09/2020).

This testimony is common to most settlers. The feeling that Filadelfia only belongs to them", because they were the first to urbanize, or conquer it, has led them to believe that they are unquestionably its rightful owners. According to their reflections, they did not need others, 
i.e. individuals who incite and motivate the dramas they now endure. A high authority of the city hall pointed this out: 'it was the incorporation of new stakeholders with different understandings of what our day to day life should be that prompted this chaos. They were not invited to join us. They moved because of the development and wealth we have in this land (Interview No. 14: Municipal Official - 09/27/2020).

The community claims that migrants and the State are to blame for the danger and uncertainty. However, in the interviews we conducted it transpired that the dangers come from the Mennonite and their lifestyle. There is no doubt that when it comes to insecurity in this community, it is evident that there is a self-established elite class unwilling to recognize that its own members have undergone a profound metamorphosis. The fact that there are youngsters who use drugs or women who have exposed their abusers, are concise proof of a congregation that is tired and expectant of important transformations, which is slowly showing.

\section{CONCLUSIONS}

Although the specialised literature has typically and classically defined insecurity as being framed by robbery, assault and damage to property or people's well-being, this article goes to show that in this case it has manifested itself in a more impersonal and indirect way. The accounts of what the original populations have endured show that perfectly legal actions, such as finding employment, can turn into nightmares when they are carried out under imposed conditions, contexts of exploitation and vulnerability. Some of these conditions can result in precariousness that can put the lives of the indigenous persons at risk, for instance, accepting work trafficking drugs.

Various theories about cases of deviance establish outsiders as the aggressors. However, according to testimonies collected within the community, the opposite was observed. The reported violations were perpetrated by members of the Mennonite community. Young Menonnite men, in their desire to break the rules, consume, sell and introduce illicit drugs into the communities. Regarding the phenomenon of violence against women, the abuses were commited by their fathers, brothers, uncles and grandfathers who forced the female members of the congregation.

What is safe and what is unsafe, as usual, is a complex issue that goes beyond a mere interpretation of the law and its applicability in the Justice System. This phenomenon is associated with its social and cultural meanings, fundamentally. Although much remains to be developed, the testimonies held by the research support its initial motion.

\section{REFERENCES}

Diario La Nación. (2020). Pista clandestina intervenida en el Chaco resulta clave en tráfico de cocaína [Clandestine landingstrip in the Chaco is key in cocaine trafficking]. Published July 18th, Asunción: Grupo Cartes.

Diario Última Hora. (2015). Indígenas tienen por primera vez su cédula de identidad [Indigenous people have their identity card for the first time]. Published July 6th, Asunción: Grupo Vierci.

Diario Última Hora. (2020). Minna articula inscripción masiva de indígenas en Registro Civil y cedulación [Minna articulates massive registration of indigenous persons in the Civil Registry and identity cards were issued] . Published October 26th, Asunción: Grupo Vierci.

Dirección General de Estadísticas, Encuestas y Censos. (2012). Atlas de Comunidades Indígenas en el Paraguay. Asunción: DGEEC-PY [General Directorate of Statistics, Surveys and Censuses. (2012). Atlas of Indigenous Communities in Paraguay. Asunción: DGEEC-PY.].

Gamarra, W. 2019. SENAD incautó $300 \mathrm{~kg}$ de cocaína en pista de aterrizaje del Chaco [SENAD seizes $300 \mathrm{~kg}$ of cocaine on the Chaco airstrip] . Filadelfia: RCC.

Ortíz, N. (2018). La drogadicción: Una realidad que no se aleja mucho del Chaco [Drug addiction: A reality not far from the Chaco]. Filadelfia: RCC.

Quiroga, L. y Ayala, O. (2014). Violencia e impunidad hacia el Pueblo Paĩ Tavyterã-Kaiowa [Violence and impunity towards the Paĩ Tavyterã-Kaiowa People]. Asunción: Tierra Viva. 
Secretaria de Estado de Tributación. (2020). Registro Público General de Grandes Contribuyentes [General Public Registry of Large Contributors]. Asunción: SET-PY. 